\section{The differences in father involvement in parenting and the anxiety level of 7-8 year-old children experiencing sexual abuse in South Tangerang City, Indonesia}

\author{
Desy Ayuningrum, Myrnawati Crie \\ Handini, Elindra Yetti
}

Doctoral Program of Early Childhood Education, Faculty of Early Childhood Education, Universitas Negeri Jakarta, Indonesia

\begin{abstract}
This study aimed to identify the relationship between father's involvement in parenting and children anxiety level. The variables of this research were the father's involvement in parenting $(\mathrm{X})$ and the anxiety level of children (Y) using a descriptive quantitative approach. The sampling technique used was purposive sampling which consisted of children within the age range of 7-8 years old who experienced sexual abuse, having biological parents, and living in South Tangerang City. A total of 14 children were taken as the samples based on the sampling technique. Data collection was carried out through the scale of father's involvement in parenting and the Spence Children's Anxiety Scale. Simple linear regression was used to test the relationship between the father's involvement in parenting and children anxiety level. The results showed that the significance score $0.000<0.05$, it means that father's involvement influenced the anxiety level of children experiencing sexual abuse.
\end{abstract}

\section{Introduction}

Children are physically more vulnerable than adults and have limited experiences which tend to influence their understanding and perception of the world. They are also the the new generations which supports and continue national ideology and dreams as well as the next human resource that develop their nation. Children rights was explicitly regulated in national law and guarantees for living, growing, developing and security from violence and discrimination. ${ }^{1,2}$

Violence disobeys human rights and affects the fulfillment of security. Sexual abuse is one of the most common crime cases in children. It includes inappropriate verbal expressions (comment, joke, and others), indecent actions (touching, fingering, stroking, hugging and others), the act of showing pornography, coercions (forced kisses and hugs), blackmail for rejections of sexual intercourse and rape. The problems of sexual abuse are deplorable because a lot of children tend to leave with its negative effect for a long time even years. These memories continuosly frighten their future life. . $^{3,4}$

National Commission of Children Protection (Komnas PA) reported that there were 2737 cases of violence towards children in 2017. According to Arist Merdeka, the Komnas PA leader, $52 \%$ of most cases were about sexual abuse. Out of the 2737 cases, 2848 were victims and 1424 were sexually abused. Furthermore, 825 (30\%) were physically hurt, 477 (17\%) psychologically abuseed, and 11 (1\%) underwent various other kinds of abuse. ${ }^{5}$

The characteristics of fathers and mothers influences the way they treat their children in various ways. Mothers are mostly much softer, while fathers stimulate their children a little "hard". These differences contribute to children's emotion. Fathers teach them how to play challenging and experimental activities such as football, wall climbing and lot more. The children are trained to compete and have better mental and physical condition, thereby exploring and improving their physical competence. The interaction between fathers and children is most often a teamwork play. The children carry out problem solving techniques, compete, and open their mind to possibilities. Moreover, they feel more energized playing with their fathers and therefore become more social and braver in expressing themselves. ${ }^{6}$

The study conducted by Robert Magnilio resulted to 4 meta-analysis, with $3,214,482$ subjects of study analyzed. The results showed that sexual abuse toward children had significant risks although it generally increased anxiety in children especially the post-traumatic stress regardless the children sex and sexual abuse level. The biological and psychosocial risks (the changes of brain function and structures, biased information processing, parents' anxiety, family disfunction, and child abuse) interacted with sexual abuse whether acted independently to influence the victims' anxiety. ${ }^{7}$

\section{Materials and Methods}

This study aimed to identify the relationship between father's involvement in parenting and children anxiety level. The
Correspondence: Desy Ayuningrum, Doctoral Program of Early Childhood Education, Faculty of Early Childhood Education, Universitas Negeri Jakarta, Indonesia, Gedung Daksinapati, Rawamangun Muka, Jakarta Timur 13220, Indonesia.

Tel./Fax: +62.21.4755115

E-mail: desyayuningrum_paud16s3@mahasiswa.unj.ac.id.

Key words: father's involvement, parenting, anxiety level, sexually abused children.

Acknowledgments: the authors would like to thank the Doctoral Program of Early Childhood Education, Faculty of Early Childhood Education, Universitas Negeri Jakarta, Indonesia.

Contributions: the authors contributed equally.

Conflict of interests: the authors declare no potential conflict of interest.

Funding: none.

Clinical trials: the study is not involved any clinical trials.

Conference presentation: part of this paper was presented at the $3 \mathrm{rd}$ International Symposium of Public Health, 2018 October 31 - November 1, Universitas Airlangga, Surabaya, Indonesia.

Dedication: the article is dedicated to Doctoral Program of Early Childhood Education, Faculty of Early Childhood Education, Universitas Negeri Jakarta, Indonesia.

Received for publication: 28 July 2019.

Revision received: 9 September 2019.

Accepted for publication: 15 October 2019.

This work is licensed under a Creative Commons Attribution NonCommercial 4.0 License (CC BY-NC 4.0).

${ }^{\circ}$ Copyright: the Author(s), 2019

Licensee PAGEPress, Italy

Journal of Public Health in Africa 2019; 10(s1):1206 doi:10.4081/jphia.2019.1206

variables of study were the father's involvement in parenting $(\mathrm{X})$ and the anxiety of 7-8 year-old children experiencing sexual abuse (Y). The quantitative approach with analysis test of simple linear is the research technique adopted. The samples were taken by using Purposive Sampling with the criteria: 1) children between the age-range of 7-8 years old; 2) children experiencing sexual abuse; 3) children with parents and; 4) children living in South Tangerang City. According to these criteria, the samples resulted in a 
total of 14 children. The data collection instruments were questionnaire of father's involvement in parenting and Spence Children's Anxiety Scale.

\section{Results and Discussion}

The results showed about the father's involvement in parenting, sexual abuse toward children and linear regression test.

The results of data taken from questionnaire were classified into three categories namely high, middle, and low involvement. Table 1 illustrates that half fathers had middle involvement in parenting $(50 \%)$.

The results from Table 2 show that the anxiety scale of children experiencing sexual abuse is categorized in three namely: high, middle, and low levels of anxiety. A total of two children $(14,29 \%)$ had low anxiety, $8(57.14 \%)$ were in the middle category, while $4(28.57 \%)$ were highly anxious.

It was found that $t$ count was -14.988 , while $\mathrm{t}$ table has the following scores $\mathrm{a} / 2=$ $0.05 / 2=0.025$ with $\mathrm{df}=\mathrm{n}-2=14-2=12$, and therefore the $t$ table was 2.179 . Because the $t$ count $-14.988>\mathrm{t} 2.179$, it can concluded that father's involvement in parenting influences children's level of anxiety (Table 3).

\section{The fathers' involvement in parenting}

Fathers should be active and participate in children activities so children will be more comfortable with their fathers. The involvement in parenting concerns the aspects of time, interaction, and attention. Lamb analysed fathers' involvement in three forms. National Institute of Child Health and Human Development in Early Child Care Research Network (NICHDECCR) mentioned the "father" factors in parenting which include job, characteristics and perspectives of parenting. While mother factors are related to marriage satisfaction and family conflict. Mother's profession determines how far fathers could contribute in parenting role. The children gender and family finance are the factors that a father considers to involve more in parenting. Fathers have a big responsibility in parenting for their role in planning, decision making and organizing things in families. ${ }^{8,9}$

Based on the data of study, fathers with high involvement in parenting role could perform five components of interaction. Firstly, they increase the frequency of meeting and interaction with children such as talking before night sleep. Secondly, they promote activities such as story telling, playing around with children and appreciating their actions sincerely. Third, improve physical contact with families such as hug- ging them. Further, fathers take care of their children's education, sometimes assisting them with their homework and in becoming their role model. Lastly, fathers develop affection and attempted to get close with their children, to be protective, and provide a positive support for their children.

Children who have bad relationships with their fathers were more vulnerable, worried and tend to have problems with eating and sexual interest during their teenage period. On the other hand, children with close relationships with their fathers grew up to be more confident. ${ }^{10}$

\section{The anxiety of 7-8 year-old children experiencing sexual abuse}

School-age children often felt anxious when they lost love, care, and support from their parents, especially those who were abused. ${ }^{11}$ Thus, children would feel depressed, consume drugs, have sleeping problems, and poor physical conditions. Two factors which are related to anxious feelings in children: self efficacy and outcome expectancy.Self efficacy means the individual capacity to face their situation. Each individual has his/her own way and capacity to get into troubles and solve them. The endurance depended on the parenting experience, life experiences, and the support from the environment. Outcome expectancy is the individual capacity to the

probability of problems happening around the children.

Children with low level of anxiety involved their fathers during interactions. On the other hand, those with high level of anxiety like to be alone, afraid of other persons, feeling guilty, ashamed, less social, facing sleeping problems, and having psychosomatic issues. Children who had experienced sexual abuse need at least 1-3 years to be more open with other people. Finkel hor and Browne underlined 4 kinds of trauma due to sexual abuse: (1) betrayal, which hurts their belief, (2) traumatic sexualization, the victim tended to refure sexual differences in their future life, (3) powerlessness, which is internalized inside their mind, started to become phobia, bad dreaming, full of anxiety, and less productive, (4) stigmatization, in which the victims fell ashamed and perceived themselves negatively. They fell different from other persons and tend to curse their condition. Most often, they start using drugs and alcohol to punish their bodies and avoid bad memories. ${ }^{12,13}$ Children with low level of anxiety adapted and socialized more easily.

\section{Conclusions}

It can be concluded that the father's involvement in parenting correlates with the

Table 1. The father's involvement in parenting.

\begin{tabular}{lccc} 
Variable & Category & Score & Percentage \\
Father's Involvement In Parenting & Low & 4 & 28.57 \\
& Middle & 7 & 50 \\
& High & 3 & 21.43 \\
Total & 14 & 100 & \\
\hline
\end{tabular}

Table 2. Sexual abuse toward children.

\begin{tabular}{lccc} 
Variable & Category & Score & Percentage \\
Anxiety & Low & 2 & 14.29 \\
& Middle & 8 & 57.14 \\
Total & High & 4 & 28.57 \\
\hline
\end{tabular}

Table 3. Linear regression test.

\begin{tabular}{lccccc} 
Model & \multicolumn{2}{c}{$\begin{array}{c}\text { Unstandardized } \\
\text { Coefficients }^{\mathrm{a}} \\
\text { Std. Error }\end{array}$} & $\begin{array}{c}\text { Standardized } \\
\text { Coefficients }^{\mathrm{a}} \\
\text { Beta }\end{array}$ & $\mathrm{t}$ & Sig. \\
B & 136.578 & 4.877 & & 28.006 & 0.000 \\
Father's Involvement & -0.750 & 0.050 & -0.974 & -14.988 & 0.000 \\
\hline
\end{tabular}

aDependent Variable: Child Anxiety Level 
anxiety of children experiencing sexual abuse. It is shown by the significance score $0.000<0.05$.

\section{References}

1. Aisyah S, Amini M, Chandrawati T, et al. Perkembangan dan KonsepDasar Pengembangan Anak Usia Dini. Jakarta: Universitas Terbuka; 2011.

2. Sugiyantica R. Implementasi Pasal 28b Ayat (2) Undang-Undang Dasar Negara Republik Indonesia Tahun 1945 Terkait Perlindungan Anak Dari Kekerasan Di Kota Surakarta 2014. Available from: https://digilib.uns.ac.id/dokumen/detail /42587/Implementasi-Pasal-28b-Ayat2-Undang-Undang-Dasar-NegaraRepublik-Indonesia-Tahun-1945Terkait-Perlindungan-Anak-DariKekerasan-Di-Kota-Surakarta. Accessed on: 11 August 2018.

3. Direktori Perlindungan Korban
Kekerasan Daerah Istimewa Yogyakarta. Badan pemberdayaan perempuan dan masyarakat. Yogyakarta: Forum Perlindungan Korban Kekerasan DIY; 2013.

4. Sumera M. Perbuatan Kekerasan/Pelecehan Seksual Terhadap Perempuan. Lex et Societatis 2013;1(2):39-49.

5. Bomantama R. Kekerasan Seksual Dominasi Kekerasan Terhadap Anak di Tahun 2017. Available from: https://www.tribunnews.com/nasional/2 017/12/27/kekerasan-seksual-dominasikekerasan-terhadap-anak-di-tahun2017. Accessed on: 29 January 2018.

6. Nugraha GP. Aku Suka Ayah Karena Ayahbunda. Jakarta: PT. Aspirasi Pemuda; 2005.

7. Magnilio R. Child Sexual Abuse in the Etiology of Anxiety Disorder: A systematic Review of Reviews. Trauma Violence Abuse 2013;14(2):96-112.

8. Andayani B, Koentjoro. Peran Ayah
Menuju Coparenting. Yogyakarta: CV. Citra Media; 2004.

9. Dwitya JA. Hubungan Keterlibatan Ayah dan Prilaku Prososial pada Anak Sulung Usia Prasekolah Terhadap Adik Bayi [Skripsi]. Depok: Universitas Indonesia; 2012.

10. Rachmani IF. Ayahku, Cintaku. Jakarta: PT. Aspirasi Pemuda; 2005.

11. Rahmayanti A. Pelecehan psikis pada anak usia sekolah dasar dan implikasinya terhadap kesehatan mental [Skripsi]. Yogyakarta: Universitas Islam Negeri Sunan Kalijaga; 2014.

12. Tower C. Understanding Child Abuse and Neglect. 5th ed. Boston: Allyn \& Bacon, A pearson Education Company; 2002.

13. Pougnet E, Serbin LA, Stack DM, et al. Father's Influence on Children's Cognitive and Behavioural Functioning: A Longitudinal Study of Canadian Families. Canadian J Behav Sci. 2011;43(3):173-82. 